\title{
Archeologies of Globalization. European Reflections on Two Phases of Accelerated Globalization in Cornelius de Pauw, Georg Forster, Guillaume-Thomas Raynal and Alexander von Humboldt
}

\author{
Ottmar Ette \\ Institut für Romanistik, Universität Potsdam, Germany \\ e-mail: ette@uni-potsdam.de
}

Received: 30 October 2011; Accepted: 16 December 2011; Published online: 09 April 2012

\begin{abstract}
In our present globalized world, an attempt to reflect on the "Archeology of Globalization" confronts us with a decisive question: Globality seems to be a singular phenomenon, the inevitable outcome of a teleological history which conforms our present. But can we think it as a plurality? Can we retrace this history in other form as a linear progression? By exploring European discussions that took place between the last third of the eighteenth and the mid-nineteenth centuries and which reflected on globalization, I will try to expose another development of this phenomenon. My focus emphasizes the very specific dynamics, modes of representation, and reflections that set up not an archeology but archaeologies of globalization: a worldconsciousness that recognizes the patterns of movement and relationality that constitutes it, transforming itself into knowledge about how to live together in difference.
\end{abstract}

KEYWORDS: Transregional mobility; TransArea Studies; Transcontinental relations; Vectoriality; New World; Discoveries; Power; Violence.

Citation/Cómo citar este artículo: Ette, O. (2012) “Archeologies of Globalization. European Reflections on Two Phases of Accelerated Globalization in Cornelius de Pauw, Georg Forster, Guillaume-Thomas Raynal and Alexander von Humboldt". Culture \& History Digital Journal 1(1): e003. doi: http://dx.doi.org/10.3989/chdj.2012.003

RESUMEN: Arqueologías de la globalización. Reflexiones europeas sobre dos fases de la globalización acelerada en Cornelius de Pauw, Georg Forster, Guillaume-Thomas Raynal y Alexander von Humboldt.- En nuestro mundo actual globalizado, el intento de reflexionar sobre la "arqueología de la globalización" nos confronta con una pregunta fundamental: la Globalidad parece ser un fenómeno singular, el resultado inevitable de una historia teleológica que conforma nuestro presente, pero, ¿podemos pensarla como una pluralidad? ¿podemos reconstruir su historia de otra forma que en una progresión lineal? Al explorar discusiones europeas que ocurrieron entre el ultimo tercio del siglo XVIII y la primera mitad del siglo XIX y en las cuales se reflexionó sobre la globalización, intentaré exponer otro desarrollo de este fenómeno. Mi enfoque enfatiza precisamente las dinámicas específicas, los modos de representación y las reflexiones que constituyen no una arqueología, sino arqueologías de la globalización: una conciencia mundial que reconoce los patrones de movimiento y de relacionalidad que la constituyen, transformándose en un conocimiento sobre cómo vivir juntos en diferencia.

PALABRAS CLAVE: Movilidad transregional; Estudios TransAreales; Relaciones transcontinentales; Vectorialidad; Nuevo Mundo; Descubrimientos; Poder; Violencia.

Copyright: (C) 2012 CSIC. This is an open-access article distributed under the terms of the Creative Commons Attribution-Non Commercial (by-nc) Spain 3.0 License. 


\section{ARCHEOLOGY OF GLOBALITY AS AN ARCHEOLOGY OF GLOBALIZATION}

The title of this first paragraph, which will also play an important role in the following reflections, may appear suggestive and captivating, but also open to and needy of interpretation. "Archeology of globality": This formula immediately poses the question how the two central concepts here might be interpreted and, maybe even more so, what kind of relationship these two semantic poles might develop and unfold.

This title, that only at first sight seems to be a common and uncomplicated notion, does not only present the challenge of demanding a methodology which must be defined and delimited in the context of archeology in the widest sense, but also of confronting us with the no less complicated problematic of having to elaborate what form of globality -be it in a climatic or biologic, a geo-ecological or spatial-geographical, a philosophical or historical, sociological or geopolitical, theological or bio-political sense-we are actually talking about. Does the metaphor for theory and science stand for a concept of history in which different strata must be unearthed stratigraphically, in order to document the presence of traces and to transform a spatial stratification into a temporal chain of events? Or could we think of archeology itself as a quality of globality, even as being its prerequisite, insofar as it permits globality to view and understand itself as a historical phenomenon and as a unity? Or does globality own-as in a genitivus possessivus-a certain archeology, its own archeology, which globality may unfold in time and space and maybe even enshroud them with? None of these interpretations seem to be excluded from the contextual frame proposed here. There also are hints that in this case globality itself could become the object of an archeology which-now not as a subiectivus but as an obiectivus-might gain power over it in order to permit us to analyze what the present of globality confronts us with as the result of a historical development, the phases of which we would have to look at more closely.

But this would -at least in my view- pose a decisive question, which I will attempt to problematize and elucidate in the following paper, not by approaching globality as a singular, but as a plurality. For speech about an archeology of globality implies a singular, but nevertheless does not define whether an ur- or early history are supposed to be analyzed as a pre-history of globality, or if the object of such archeology may also include earlier forms of the former which are not part of a pre-history, but constitute an essential element of globality in its temporal and spatial transition. To what extent we will wish to attribute a spatial and historic phenomenon (and our knowledge about it) to a history of globality or, alternatively, "only" to its pre-history, will depend decisively on how globality is defined and exactly what phenomena we are trying to investigate. How could we, then, conceptualize globality in the plural?

It is inevitable to make a limitation at this point. For in the following paper I only want to examine the European tendencies of reflection that took place between the last third of the eighteenth and the mid-nineteenth centuries. Only in passing will I refer to non-European modes of understanding and constructing globality. Hereby the following thoughts will not so much try to analyze an archeologically-defined state of affairs, be that what it may, of globality in its historic stratification, but, rather, they will try to remind us of the historic process of development itself by focusing on the very specific dynamics, modes of representation, and reflection on globalization. By changing our orientation and by focusing on the dynamic and processual character of the global, we evidently cannot avoid the problem of having to state precisely whether we want to attribute certain historical phenomena to the history or the pre-history of globalization. Our understanding of globality and of globalization depends on the answer to this question-at least when it comes to the meaning of the terms which ground the reflections about the archeology of knowledge that I want to present here.

Such a definition does not lack current (political) dynamite, even though it may also seem somewhat abstract and distant. This can be proven by taking a look at the preliminary report on the "Globalization of the world economy-challenges and answers" that a commission of inquiry sponsored by the German Bundestag presented after long discussions on September 13th, 2001, that is to say: immediately following the devastating terrorist attacks on the World Trade Center and other targets in the USA.

In an analysis of the "career of the word globalization" based on its appearance in the Frankfurter Allgemeine Zeitung, it is proven that the word globalization only became popular in German-speaking countries by the 1990s increasing significantly throughout the decade: Starting with 34 appearances in 1993, it was used more frequently in 1995 (175 appearances), in 1996 (535 appearances) and in 2000 (1062 appearances) (Deutscher Bundestag, 2001: 3). Today, everybody uses the word, and it is beginning to lose all contours as it is being used as a token in the most diverse discourses, spread by the mass media. But how does the above-mentioned report define "globalization?" 
In concordance with the commission's line of inquiry, the term "globalization" is defined and discussed mainly -without excluding other possibilities completely- in an economic sense:

\begin{abstract}
"Globalisierung ist zunächst die weltweite wirtschaftliche Verflechtung. Vor 1990 war das Wort Globalisierung kaum in Gebrauch. Vielleicht wurde von der Internationalisierung der Wirtschaft gesprochen, die schon früher einsetzte. Sie hatte ihre Ursprünge in den Jahrhunderten der (europäischen) Seefahrer und setzte sich-auf tragische Weise-während der Kolonialzeit des 19. Jahrhunderts fort. [...] Mit dem technischen Fortschritt beim Verkehr und der Kommunikation wurde die wirtschaftliche Verflechtung der Staaten, Regionen und der Erdteile immer intensiver. Später haben auch politische Zielsetzungen der regionalen Integration und der Friedenssicherung die wirtschaftliche Verflechtung gefördert." (Deutscher Bundestag, 2001: 2)
\end{abstract}

The extremely vague and undefined references to the times of the European mariners and the colonialism of the nineteenth century, which is left in the dark, make it clear that such phenomena are viewed at best as a marginal pre-history of globalization and that, following the commission, they have contributed little to the signification of this lexeme -also considering its late emergence. What is more: The centuries of colonization and colonialism don't seem to have much to do with today's phenomenon, given the fact that a clear line is drawn between them and the term "globalization." "The" globalization thus turns into a singular phenomenon appearing by the late twentieth and early twenty-first centuries and does not only manifest itself as something new on the level of words, but also -as Michel Foucault (1966) would have it in his understanding of archeology- on the level of things. But we will have to ask if it is adequate, justifiable and useful to describe globalization as something completely new.

Let's make it clear: Such an understanding of globalization is by no means limited to politics, economics, or the broad public, but it also appears frequently in the field of science. In a different publication, I have tried to put forward against this tendency an understanding of globalization as a process de longue durée which is characterized by various phases of acceleration and which underlies and connects in complex ways modernity and postmodernity (Ette 2004).

My approach takes four phases of accelerated globalization as a point of departure. Each of these four phases can be differentiated from one another by telltale characteristics typical of each phase and can be assumed to begin with the moment in which it became possible for the first time to circumnavigate the globe by ocean and using modern navigation technology, thus establishing and, notably, maintaining a first, still rudimentary system of communication and transportation on a global scale. This does not exclude further, "intermediate" phases of acceleration. Seen from this perspective, Cristóbal Colón's project of reaching India by the westward ocean route reveals itself to be an evidently global enterprise, making use of the older knowledge about the spherical shape of the earth and combining it with the most recent knowledge of seafaring and navigation.

From this perspective, which can only provide a brief overview, the first phase of accelerated globalization appears as a global colonial expansion, mostly by the Iberian powers, which relied on advances in the art of seafaring and herewith made the "discoveries" of the fifteenth century possible. ${ }^{1}$ The second phase of accelerated globalization stretches from the mid- to the late eighteenth century and was carried out mainly by France and Great Britain -this relying in part on institutional and economic progress and successes of the Dutch in the seventeenth century, which simultaneously display a basic tendency of "retard" and "prescience." In this phase, a more intensive system of trade and communication was put into place, dictated by European interests and operated from London, Paris and Amsterdam, a system which implemented innovative forms of presenting and arranging knowledge, following the needs of European political power and science.

In the third phase of accelerated globalization, the United States of America joined the European powers in the last third of the nineteenth and the beginning of the twentieth century as the first non-European power (even though it bore a strong European influence, of course). This power would take an active part by the means of forceful military interventions in sea-based operations in the neo-colonial struggle for riches and in the processes of modernization encompassing the most diverse regions of the planet. The year 1889 marks an important, maybe decisive turning-point here, with the United States' intervention in the SpanishCuban war, which not only began the long string of US interventions in the American hemisphere and, later, in the whole world, but also represents the first act of war which was mediatized globally by using the most modern communications technology between Cuba and the Philippines, the USA and Spain. With this, wars at the other end of the planet had begun to turn into a life-knowledge that was going be experienced in the twentieth century by the means of mass media.

Finally, the time span analyzed by the German Bundestag's commission constitutes a fourth phase of accelerated globalization, a phase whose 
processes of acceleration have not (yet) reached their conclusion today and which consist mainly in the establishment of global networks for information exchange, the rapid increase in money flows of a global reach and the supersedence of an ideologically and power-politically motivated division of the world into two competing blocks, armed with nuclear weapons. The globalized networks of communication and information superhighways created for the military, mass-media and mass-culture which are typical for this phase certainly have also brought with them new forms of perceiving and being sensitive to a (not just discursive) "global society in the making" (Albert, 2002: 340). But, when observing this kind of phenomena, one shouldn't, fascinating as it may be, forget to apply some historic focus, so that what came before may not slip away into some indistinct murkiness. The current phase of accelerated globalization is something specific, but by no means is it something completely new.

My contribution to an archeology of globality takes itself to be, up against this backdrop, a project concerning the archeology of globalization which addresses these earlier, historic reflections on globalization. Hereby I will focus on authors and texts that prove to have attempted-more or less consciously-to draw a connection between the contemporaneous phase (or the study of the immediately preceding phase) and earlier phases of accelerated globalization.

The Berlin of the eighteenth and nineteenth centuries was certainly not a place of high globalism or a highly condensed form of globalization. And still the following thoughts, in the context of a paper on an archeology of globalization, will concern themselves mainly with debates, polemics and scientific investigations which took place and were presented in Berlin and Potsdam. So, as a side effect, a contribution to a history of globality in this particular region might result. There can be little doubt that there is still much archaeological work to be done, particularly because this (hi)story lies buried under the rubble of later historical events and catastrophes, the collective "commemoration" of which has a tendency to hinder truly historical approaches to the past, especially in this part of the country. At the same time, there is hope that the common practice of reducing everything that precedes the twentieth century to a mere pre-history will generate more uneasiness in the near future. With respect to the historical events and discourses which shall be treated here, it is a surprising fact that these discussions - which were well known far beyond the borders of Prussia and Europe- have been almost completely forgotten and erased in the collective memory of this German region.

\section{PHILOSOPHICAL REFLECTIONS ON AMERICA AS PHILOSOPHICAL REFLECTIONS ON EUROPE}

Right at the beginning of his "Discours préliminaire" to the first volume of his Recherches philosophiques sur les Américains, published in 1768 in Berlin under the name of a certain "Mr. de P***," Cornelius de Pauw left no doubt that the voyage(s) of Christophe Colomb, alias Christopher Columbus, were literally of worldhistorical importance:

\begin{abstract}
"Il n'y a pas d'evénement plus mémorable parmi les hommes, que la Découverte de l'Amérique. En remontant des temps présents aux temps les plus reculés, il n'y a point d'evénement qu'on puisse comparer à celui là; \& c'est sans doute, un spectacle grand \& terrible de voir une moitié de ce globe, tellement disgraciée par la nature, que tout y étoit ou dégéneré, ou monstrueux.
\end{abstract}

Quel Physicien de l'Antiquité eut jamais soupçonné qu'une même Planète avoit deux Hémisphères si différents, dont l'un seroit vaincu, subjugué \& comme englouti par l'autre, dès qu'il en seroit connu, après un laps de siécles qui se perdent dans la nuit \& l'abyme des temps?

Cette étonnante révolution qui changea la face de la terre \& la fortune des Nations, fût absolument momentanée, parce que par une fatalité presqu'incroiable, il n'existoit aucun équilibre entre l'attaque et la défense. Toute la force \& toute l'injustice étoient du côté des Européens: les Américains n'avoient que de la foiblesse: ils devoient donc être exterminés $\&$ exterminés dans un instant. (Pauw, 1768-1769, I: a2v f.)",2

From the first pages on, Cornelius or Corneille de Pauw, who was born in Amsterdam in 1739, spent a part of his youth in Liège and received his education at the Jesuit schools of Liège and Cologne, as well as possibly attending the University of Göttingen for a while, emphasized oppositions and drew a boldly colored image that was rich in contrasts and antinomies. ${ }^{3}$ This opposition between two completely different hemispheres, which he underlined and constructed time and again, applied to the characteristics of natural spaces on the "old" and "new" continents, as well as all life that might thrive in these two "worlds." De Pauw tried to insert all the isotopies that would mark his Recherches philosophiques as a whole into the incipit of his work: this has to be considered a literary and rhetorical effort, the often polemical gist of which - to which de Pauw's rapid fame and equally rapid disappearance into oblivion were owed-did not fail to make an impression on the 
contemporary international readership. Old and New World thus stand in irreconcilable opposition.

But the superlatives and oppositions do not only encompass the realm of nature in the New World, in which everything seems to be "degenerate and monstrous," but also and especially the processes of history: May the "discovery of America" represent the "most noteworthy event in the history of mankind,"4 the immediately ensuing "conquest of the New World" ("conquète du Nouveau Monde"), in contrast, constitutes "le plus grand des malheurs que l'humanité ait essuié" (Pauw, 1768-1769, I: a3v). A hemisphere of superior power, which will not hesitate to make ruthless use of this power, sees itself confronted with a hemisphere of weakness, the Old World and the New World, the latter being inferior and subordinate in all things: More than once, de Pauw insists on the abruptness of the decline that the fateful arrival of the Europeans meant for the Americans. A struggle between the powerful and the weak, almost Darwinist from today's perspective, leads to the predictable ending.

No harmony can be found anywhere in de Pauw's black and white sketch: The earth reveals itself to be a planet of disharmony. This takes on extreme forms, which the thinkers of antiquity that is, of a world that had no inkling of the other world's existence- could never have anticipated. When it comes to showing off in a spectacular way, it is hard to rise above de Pauw's incipit. It opened a debate, initially based in Berlin and led in French, that without a doubt went back to disputes of the Spanish sixteenth century, but gave the latter a new twist by corresponding to state-of-the-art Siècle des Lumières science and, importantly, Buffon's Histoire naturelle. We could designate this phase of the disputes as the "Berlin debate" about the world outside Europe -a debate that of course did not restrict itself to Berlin and Potsdam.

Still, this bipartite world is one-and both hemispheres, it quickly becomes clear, are inseparably intertwined and chained to one another. Right in the first lines of his work, Cornelius de Pauw reveals himself to be a thinker of globality, or more precisely: a thinker of a globality that is characterized by a sharply asymmetrical structure. This asymmetrical structure brought with it the fact that the old America, "l'ancienne Amérique," still familiar to the Conquista's contemporaries, is no more. It has been "entièrement bouleversé par la cruauté, l'avarice, l'insaciabilité des Européens" (Pauw, 1768-1769, I: a4r). The Spanish conquistadors have turned into Europeans, and the destructive violence they engender is swiftly put into a perspective by de Pauw that opens up to potential catastrophes of a global scale. Suddenly, the man-made extinction of mankind becomes a possibility, an "extinction totale" (Pauw, 17681769, I: a3r), which would not be caused by a natural catastrophe, but by human actions. For it is up against the backdrop of the colonial expansion that took place in the fifteenth and sixteenth centuries that de Pauw points out the consequences of this second wave of expansion which was spreading from Europe across the globe, an expansion of which the Dutch Abbé was a contemporary and a witness. Europe, says de Pauw, is about to take hold politically and scientifically of the "Terres Australes," under the guidance of "politiques" and the approving applause of some "philosophes," without reflecting on the considerable misfortune it is bringing over the peoples that live there (Pauw, 1768-1769, I: a3r). This does not only concern the European policy of expansion in a military and scientific sense, but also- and notably - the local sciences in Europe and their very own interests. Following de Pauw, "la destruction d'une partie du globe" would be accepted generally if it allowed to clarify some of the debated geographical questions and permitted to execute verifiable temperature measurements (Pauw, 17681769, I: a4v). The European sciences and their inner logic are represented here very clearly as both the motivators and instruments of the European politics of expansion. But such a development should be opposed: "Mettons des bornes à la fureur de tout envahir, pour tout connoître" (Pauw, 17681769, I: a4v). Knowledge is not only power here, but carries within it -also and especially in the epistemological hunger of European science- the potential and capacity for destruction and selfdestruction.

But no international debate ensued from this. For it is here that Cornelius de Pauw states his point of view, completely ignored so far: in the critical reflection on the first European global expansion, seen in the light of the renewed expansive drive of the second half of the eighteenth century, this movement now not just being "accompanied," but demanded and propelled by scientific investigation and "penetration." The sharp-tongued Dutch cleric, who had enjoyed royal favors twice at the court of Frederick the Great -first in 1767 and 1768, then in 1775 and 1776- and who Antonello Gerbi (1983: 117) dubbed the "abbate prussiano" in view of his later, long years in Xanten, had gained awareness of the destructive and self-destructive logic of a historical development in which that what was occurring in Europe could have immediate consequences and repercussions in the whole world, for all of humanity. For a long time, he remarked, especially in the colonies, the conflicting interests of the Europeans had reached a point at which a small spark would suffice to make everything go up in flames: 
"[...] une étincelle de discorde, pour quelques arpents de terre au Canada, enflamme et embrase l'Europe; $\&$ quand l'Europe est en guerre, tout l'Univers y est: tous les points du globe sont successivement ébranlés comme par une puissance électrique: on a agrandi la scene des massacres et du carnage depuis Canton jusqu'à Archangel; depuis Buénos-Aires jusqu'à Quebec. Le commerce des Européens ayant intimement lié les différentes parties du monde par la même chaîne, elles sont également entraînées dans les révolutions $\&$ les vicissitudes de l'attaque $\&$ de la défense, sans que l'Asie puisse être neutre, lorsque quelques marchands ont des querelles en Amérique, pour des peaux de Castor, ou du bois de Campèche." (Pauw, 17681769, I: 90)

It had already become clear in the eighteenth century that conflicts in world trade were susceptible of escalating to military confrontations that may well be designated as world wars. The smallest events were therefore capable of triggering European clashes on the whole globe and of bringing war to the seemingly most remote and far-away territories on both hemispheres. It is quite noteworthy here that de Pauw chose to use in the first volume of his Recherches philosophiques (published in 1768) the North American fur trade as an example for a reason entailing the globalization of war, because he herewith focused on a constant conflict zone between British, French and Spanish interests in America. A fight over some badgers-wasn't that a completely inappropriate example when it came to making his thesis of a possible worldwide conflict more plausible?

It is as instructive as it is revealing that nobody less than Georg Forster, who had accompanied James Cook on his second voyage around the world together with his father Reinhold, also chose the example of the badger furs to reflect on some events of the globalization process that, from his point of view, were of a totally different nature. For the famous author of the Reise um die Welt, first published in English in the year of 1777, then in a German edition from 1778 to 1780 and highly respected by Alexander von Humboldt, relied on exactly this example. ${ }^{5}$ In an extensive text about "Die Nordwestküste von Amerika, und der dortige Pelzhandel" ("The Northwestern Coast of America and the Fur Trade there"), published in 1791 -that is to say, following the French Revolution-, he used this seemingly marginal trade as a point of departure for more fundamental thoughts:

\footnotetext{
"Der Zeitpunkt nähert sich mit schnellen Schritten, wo der ganze Erdboden dem Europäischen Forschergeiste offenbar werden und jede Lücke in unseren Erfahrungswissenschaften sich, wo nicht ganz ausfüllen, doch in so weit ergänzen muß, daß wir den Zusammenhang der Dinge, wenigstens auf dem Punkt
}

im Äther den wir bewohnen, vollständiger übersehen können". (Forster 1985: 390)

Here, Georg Forster is underscoring those rapid advances of a European knowledge about causal connections in the planetary space which are without a doubt mainly the result of the scientific expansion that took place in the course of the second phase of accelerated globalization. Not only have "unsere jetzige physische und statistische Kenntniß von Europa zur Vollkommenheit gediehen, sondern auch die entferntesten Erdteile" ("our current physical and statistical knowledge about Europe been completed, but also the most remote parts of the world") stepped out of the shadow "in welchem sie noch vor kurzem begraben lagen" ("in which they lay buried until most recently") (Forster 1985: 393). The light metaphor characteristic of Enlightenment thought illuminates Forster's own standpoint very clearly: The voyages of James Cook, he states, brought about much new information, so that "ohne ihn wohl schwerlich der Pelzhandel zwischen China und dieser neuentdeckten Küste zu Stande gekommen und zwischen den Höfen von Madrid und London eine Kollision desfalls entstanden ware" ("without him the trade in furs between China and this newly discovered coast would hardly have been possible, much less a conflict between the royal courts of Madrid and London") (Forster 1985: 395). But warlike conflicts ensuing from such collisions of interests are not the main interest of Forster's literally prophetic world-historical reflections. The immense acceleration he had witnessed led Forster to believe that a new historical epoch had begun, an epoch of an undoubtedly global format:

\footnotetext{
"Hier beginnt eine neue Epoche in der so merkwürdigen Geschichte des Europäischen Handels, dieses Handels, in welchen sich allmählig die ganze Weltgeschichte aufzulösen scheint. Hier drängen sich dem Forscher so viele Ideen und Thatsachen auf, daß es die Pflicht des Herausgebers der neuen Schifffahrten und Landreisen in jener Gegend mit sich zu bringen scheint, alles, was auf die Kenntniß derselben Beziehung hat, in einen Brennpunkt zu sammeln und zumal einem Publikum, wie das unsrige, welches nur einen litterarischen, mittelbaren Antheil an den Entdeckungen der Seemächte nehmen kann, die Übersicht dessen, was bisher unternommen worden ist, und das Urtheil über die Wichtigkeit dieser ganzen Sache zu erleichtern". (Forster 1985: 395)
}

This passage is very revealing to us not only because it reflects on the specific situation of the German public, which-as not belonging to the public of the naval and colonial powers-does not have any particular colonial interests and sympathies, therefore only being interested in augmenting 
its knowledge by making use of the written text as a medium. Rather, the thesis about a new epoch that Georg Forster develops from the fur trading activities in North America, ${ }^{6}$ an epoch in which all of world history is going to dissipate into world trade, is of so vast an outreach in the context of the philosophy of history that one has to be clear on two special points. Firstly, we must acknowledge the foresight involved in a subtle reflection on the consequences of the second phase of accelerated globalization, in which the author of $A$ voyage round the world was involved himself. Secondly, we must take note of the more general phenomenon that phases of acceleration create, seen from the philosophy of history, a kind of stroboscopical effect. For exactly like the wheels of carriages or wagons in the classic Western seem to stand still just when they're turning at maximum speed, in the phases of historical acceleration an impression of immobility, of a "post-histoire," seems to predominate, the perception of which seems to be continuously running alongside the development of a modern historical way of thinking.7 The impression of total calm usually arises at the center of accelerating, circular movement.

Just where in Georg Forster's reflections worldhistory disappears and transforms into world trade, making room for a time after history, Cornelius de Pauw's Recherches philosophiques sur les Américains unfolds a paradoxical temporal phase. It is that phase of a post-human history in which a history of the planet earth without humans becomes imaginable, that is to say, a man-made extinction of mankind which appears as the result of a European movement of expansion comprising also -and specifically - the sciences. Humanity's phase after history and the historic phase after humanity, the dissolution into world trade and into an apocalyptic flame seem to be two sides of the same coin, a coin that only circulates in times of great acceleration and upheaval. Here, de Pauw is not only thinking of the wars with which Europe covered the other hemisphere from the Conquista's days on, but certainly also of the plagues which created a strange symmetry by leading to devastating consequences in the other hemisphere, respectively. The genocide committed against the Indians soon turns against the Europeans in de Pauw's concept of history, the Europeans seeing themselves plagued by imported epidemics:

\footnotetext{
"Après le prompt massacre de quelques millions de Sauvages, l'atroce vainqueur se sentit atteint d'un mal épidémique, qui, en attaquant à la fois les principes de la vie \& les sources de la génération, devint bientôt le plus horrible fléau du monde habitable. L'homme déjà accablé du fardeau de son existence, trouva, pour comble d'infortune, les germes de la mort entre les bras du plaisir \& au sein de la jouissance: il se crut
}

perdu sans ressource: il crut que la nature irritée avoit juré sa ruine". (Pauw, 1768-1769, I: a3v)

In the course of his Recherches philosophiques, de Pauw not only illustrates more than once the dangerousness of syphilis, which was commonly attributed to the American continent, but also emphasizes the quickness of the worldwide spreading of a disease which -comparable to the fourth phase's immune deficiency syndrome- awaits men in the arms of desire and by the breast of lust, according to de Pauw. The Dutch cleric, whose detailed representations of sexual practices (mainly in the second volume) would merit an investigation of its own in the context of a historiography which enforces gender hierarchies, assembles the reports known to him and underlines that this affliction has spread all over the globe since Christopher Columbus' return to Spain in 1493:

\footnotetext{
“Ceux qui ont prétendu qu'il n'est parvenu en Russie que sous le regne de Pierre premier, ignorent apparemment qu'il sévissoit déjà en Sibérie dès l'an 1680, \& s'étoit manifesté plus de soixante ans auparavant à Moscow, de sorte qu'il avoit achevé le tour du Globe, si l'on en excepte les Terres Australes, en 1700". (Pauw, 1768-1769, I: 237)
}

According to de Pauw, contemporaries could count themselves lucky that the discovery of America hadn't occurred during an epidemic of leprosy, so frequent in the Middle Ages, for the "funeste combinaison" of two so dangerous diseases in the midst of Europe would have entrained completely unforeseeable consequences (Pauw, 1768-1769, I: 238). Experiencing globalization(s) thus implicates for Europe -so one could say on the basis of the Recherches philosophiques- experiencing a threat, be it wars (which, naturally, were preferably relegated to the world outside Europe), or be it sicknesses, which could reach Europe's heart from the most remote areas of the globe. The important fact that Europe might be existentially threatened by epidemics and pandemics is an integral part of the experience of globality, the archeology of which could easily prove the continuity of this periodic European fear of calamities which might intrude from distant regions of the world. An archeology of globality cannot be imagined without an archeology of the fears and threats arising from globality.

In Georg Forster, as in Cornelius de Pauw, philosophical reflections about America reveal themselves, under the mark of globality and up against the backdrop of two phases of accelerated globalization, which are to be kept separated, to be always also -and specifically- philosophical reflections about Europe and its place in the world, in world-history and world trade. Herein lies the 
specific meaning of that antagonistic construction of the world which de Pauw unfolded in his Recherches philosophiques and which constructs two hemispheres which are diametrically opposed on all levels:

\begin{abstract}
"La différence d'un Hémisphère à l'autre étoit donc totale, aussi grande qu'elle pouvoit l'être, ou qu'on puisse l'imaginer. Je conviens qu'il est difficile de rendre raison d'une si étonnante disparité entre les deux parties constituantes d'un même globe". (Pauw, 1768-1769, I: 95)
\end{abstract}

But the effective functionality consisted in its capacity to constitute America literally as the radical Other, with a view to a Europe that could, by these means, become aware of its own superiority and civilizing mission, but also of the threats endangering it. It had long since become impossible to conceive Europe as a multi-faceted entity beyond and apart from this form of globality and its phases of accelerated globalization.

\section{A COLONIAL HISTORY AS THE FORGOTTEN HISTORY OF THE COLONIAL PERIOD}

From the very start, the reception in the European and non-European République des Lettres of the eighteenth and early nineteenth centuries, which set in immediately after the publication of the first volume, concentrated on the thesis of an essential and natural inferiority of the New World and its inhabitants, perpetuatingcertainly not without a good reason-an understanding of the work as "probably the most scathing denunciation of America and everything American that was ever written" (Church, 1936: 179). As we have seen, from the first page of his Recherches philosophiques on, de Pauw left no doubt that everything on the "other half of the globe" was naturally "disfigured," "degenerate," and "monstrous" (Pauw, 1768-1769, I: a2v).

Here, Cornelius de Pauw no doubt was situated in a discursive line of tradition -a large number of academic investigations having proven this clearlywhich on the one hand goes back to the enormous Histoire naturelle of Buffon's, ${ }^{8}$ but on the other hand takes up lines of argumentation leading back to the early debates from the first years of the sixteenth century between Las Casas and Sepúlveda and insofar also include descriptive and discursive elements from Aristotle's notorious justification of a naturally "given" form of slavery. ${ }^{9}$ There is no denying that de Pauw's two-volume work inscribes itself into this double discursive tradition, and there can be just as little doubt that this temporary resident at the court of Frederick the Great was busy radicalizing his thesis of inferiority, extending it widely to the indigenous population of the New
World. Of this latter act he could very well suppose that -aside from all criticism of a European attitude that had abused its unquestioned "superiorite" in all respects (Pauw, 1768-1769, I: a3r) - it would meet the firm opposition of all those who, whether sympathetic of the famous Discours sur l'origine et les fondements de l'inégalité parmi les homes (Rousseau, 1975) ${ }^{10}$ or not, believed themselves to be adherents of the thesis of the "noble savage." Nothing can be felt here of the bon sauvage, or of what Bernardin de Saint-Pierre later termed the Harmonies de la nature. For all those who still hadn't grasped this position while reading the first volume, de Pauw presented passages in the second volume, published in 1769, which did not lack clarity and pointedness. There we learn about the human species:

\begin{abstract}
"Le véritable pays où son espèce a toujours réussi \& prospéré, est la Zone tempérée septentrionale de notre hémisphère: c'est le siége [sic!] de sa puissance, de sa grandeur, \& de sa gloire. En avançant vers le Nord, ses sens s'engourdissent \& s'émoussent: plus ses fibres $\&$ ses nerfs gagnent de solidité \& de force, par l'action du froid qui les resserre; $\&$ plus ses organes perdent de leur finesse; la flamme du génie paroît s'éteindre dans des corps trop robustes, où tous les esprits vitaux sont occupés à mouvoir les ressorts de la structure \& de l'économie animale. [...] Sous l'Equateur son teint se hâle, se noircit; les traits de la physionomie défigurée révoltent par leur rudesse: le feu du climat abrége [sic!] le terme de ses jours, \& en augmentant la fougue de ses passions, il rétrécit la sphère de son ame: il cesse de pouvoir se gouverner lui-même, et ne sort pas de l'enfance. En un mot, il devient un Nègre, \& ce Nègre devient l'esclave des esclaves.

Si l'on excepte donc les habitants de l'Europe, si l'on excepte quatre à cinq peuples de l'Asie, \& quelques petits cantons de l'Afrique, le surplus du genre humain n'est composé que d'individus qui ressemblent moins à des hommes qu'à des animaux sauvages: cependant ils occupent sept à huit fois plus de place sur le globe que toutes les nations policées ensemble, $\&$ ne s'expatrient presque jamais. Si l'on n'avoit transporté en Amérique des Africains malgré eux, ils n’y seroient jamais allés: les Hottentos ne voyagent pas plus que les Orangs [...]”. (Pauw, 1768-1769, II: 68 ff.)
\end{abstract}

From the perspective chosen here, it is of utmost importance that the Dutch philosophe highlights traveling and, herewith, mobility in a spatial sense as that characteristic feature which distinguishes the "higher" from the "lower" human being, and humans from the great apes, from animals. If one were to consider as mere "Eurocentrism" such an understanding of the Europeans as the glorious peak of mankind and of the vast majority of non-European peoples as being closer to animals 
than humans, therefore rightfully enslaved, one would be downplaying this attitude irresponsibly.

But de Pauw's calculated foundation of his theses in the polemical discussion and radical overstatement of contemporary scientific works led to the desired result. Only shortly after the publication of the second volume of de Pauw's writings, Antoine-Joseph Pernety, a former Benedictine who had traveled as a ship's chaplain with Bougainville on the latter's 1763 voyage to the Falkland Islands and was now under the protection of Frederick the Great as a librarian, opposed the Dutch's theses publicly in a lecture given at the Berlin Academy on 7 September 1769 and published, only a year later, his Dissertation sur l'Amérique et les Américains, contre les Recherches philosophiques de $\mathrm{Mr}$. de $\mathrm{P}^{* * *}$. ${ }^{11}$ The "Berlin Debate" had begun, and its repercussions - which went far beyond the borders of Europe- are well known. De Pauw had only been waiting for this opportunity to counter-attack, which would amount mainly to an inversion of his negative image of the Americans into an idealized representation of everything American, and placidly had Pernety's attacks printed in the extended threevolume edition of his Recherches, published in Berlin in 1770 . To this edition, he added a violent, but well-measured argument in defense of his increasingly popular and influential theses (Pauw, 1770). ${ }^{12}$ Of course one can find "elements of a modern ethnological attitude" in Pernety's text (Mannucci, 1992: 384), ${ }^{13}$ but still his line of argumentation remained closely attached to the theses brought forward by de Pauw, which Pernety frequently simply inverted. The fact that de Pauw was charged with writing the extensive first part of the Encyclopédie's article on "Amérique" in 1776, mentioned above, should prove, among other events, that from that moment on he was considered a specialist on America and was to keep the upper hand in this and other conflicts, at least for a while. Presenting himself as a well-informed eyewitness (with a view to his voyage to the New World at Bougainville's side) had been of no help to Pernety: de Pauw, who had never even attempted to verify his "investigations" about the Americans locally, was the man of the hour, and his oeuvre would remain at the center of the worldwide debates he had caused about America and the Americans.

Ever since the controversy with Pernety about whether the Americans (or savages) might be inferior or superior to the Europeans, the Recherches philosophiques were repeatedly and preferably reduced to the extreme thesis of an inferior America and inferior Americans, a perception which marks the very sporadic attention that has been paid to de Pauw in the twentieth century, by the way. As strong and enduring as the reactions to de Pauw's main work may have been until well into the nineteenth century (Church, 1936: 194, 205): such a reading led to de Pauw being largely ignored later on, only to be mentioned in a couple of sentences while moving on to more important authors. By the mid nineteenth century at the latest, de Pauw's name had disappeared once and for all from the debates about the New and the Old World: only a few specialists, so it seems, were still interested in his writings.

But still, one shouldn't underestimate the influence this work, published in French almost two and a half centuries ago in Berlin, has had in the long run (Gerbi, 1983: $118 \mathrm{ff}$.). Nor should one make the mistake of reducing the entire oeuvre to the inferiority-thesis. Supposedly, no new aspects are to be gained from this line of reception, from which Susanne Zantop -who tragically died a few years ago - tried to break lose by inquiring into whether there was a possibility of reading de Pauw's Recherches as "symptomatic for Enlightenment thought." This insofar, as de Pauw's seemingly rationalistic explanatory patterns seemed to transform abruptly, following Max Horkheimer's and Theodor W. Adorno's Dialectic of Enlightenment, into "mythical dread" of the Other and into attempts of subjugating and dominating the Other (Zantop, 1993: 315). But it was just this specific dimension, according to Zantop, that made de Pauw attractive for the Prussian monarch and the Germans as a whole, who -apart from isolated connections- had only entertained an intellectual relationship with the New World (Zantop, 1993: 316), an argument we had already seen in Georg Forster's text of 1791. De Pauw's text, she says, might well be read as "an invitation to colonial activities «on all fronts»," insofar as it assured its German readers that they hadn't, up to date, been responsible for any crimes in colonial history, a history that de Pauw had criticized from the beginning as a string of bloody atrocities (Zantop, 1993: 316). The message to the Prussian and German readership had been clear: If the necessary colonization of the Americans by a civilized people, with a bent for the fine arts and thriving sciences, loving organization and hard work, had to be undertaken, then the Prussians and Germans should be prepared for such a task and take advantage of the next opportunity.

Without a doubt, connecting de Pauw's theses with Horkheimer's and Adorno's approach is an exciting and fruitful line of inquiry, for it may be possible to give the Dialectic of Enlightenment a new twist by taking into account the question of the inferiority or superiority of the indigenous American peoples. Especially de Pauw's extreme exaggeration in making his claim for superiority might be approached from the perspective of the dialectic inherent in the Enlightenment, revealing 
its totalitarian traits - even though de Pauw, as we have seen, formulated his violent skepticism concerning the second phase of accelerated globalization at the beginning of his work. But first, one would have to take note of the fact that such a line of argumentation might explain the Recherches philosophiques' success in Prussia and the German-speaking countries, but that it would fall short of explaining the success they had in all of Europe if one doesn't count Spain, which de Pauw attacked with special vehemence. Additionally, Susanne Zantop does not make clear in how far de Pauw's text actually had such an effect and whether this "impact" can really be documented in Prussia and Germany.

On the other hand, it cannot be denied that one may attribute to the Recherches philosophiques sur les Américains a long-term and often subcutaneous effect. This influence cannot simply just remain attached to an explicit reference to de Pauw's name. But most of all -and I would underline this as being of even greater importance for the questions I am dealing with here-de Pauw, who quickly withdrew from his rather short stints in Berlin and Potsdam to Xanten (where he died in 1799), knew how to use the newly developing public sphere for his ends. For it was the success of his text, printed and polemically discussed in Berlin, what made heads turn in the French-language République des lettres and drew public attention to a once rather marginal region that certainly wasn't known for its global connections. But it was just there that subjects of world-historical relevance and questions concerning the philosophy of history were now being discussed in public, so that Berlin turned, in a way, into an important point of intersection for debates which were taking place, with increasing intensity, on both sides of the Atlantic.

Undoubtedly, this was something completely new, even though Brandenburg and Prussia hadn't at all refrained in their history from all kinds of colonial activity -this fact contradicting a commonplace perception. The Amsterdam-born Abbé most certainly noticed that already the Great Elector ("Großer Kurfürst") had been looking closely at plans for colonial expansion and that he had made first steps toward a colonial "engagement" of his country. For Frederick Wilhelm I. (1640-1688) had studied at Amsterdam and had observed at close range how ocean trade and colonial politics were capable of rapidly elevating even a small country to the status of an internationally leading tradingpower (Lennert, 2004: 11). In 1647, a former Dutch admiral, Arnoult Gijsels, now an advisor to the Elector, proposed the foundation of a house of commerce under Brandenburg's leadership. Simultaneously, negotiations with Denmark about acquiring the Danish base of Tranquebar on the African coast were in progress (Lennert, 2004: 11).
But real breakthroughs were long in the making. Again it was a Dutchman, the outfitter Benjamin Raule, who helped Brandenburg in building up a fleet and who was designated, in 1677, "Oberdirektor in Seesachen" ("High director of naval affairs") and rose to be minister for seafaring and the colonies later on (Lennert, 2004: 12). In 1680, two expeditions under Brandenburg's flag finally went to sea. On the so-called Gold Coast in today's Ghana, Brandenburg's first colonial base, Großfriedrichsburg, was in fact established in the immediate vicinity of Dutch and British settlements, controlling a coastal stretch of about 50 kilometers. In the meantime, the second Brandenburgian fleet off the coast of Ostende managed to take hold of the Spanish ship "Carolus Magnus," which then began a second career as the flagship of Brandenburg's fleet, the "Markgraf von Brandenburg" (Lennert, 2004: 12 f.). Following the Brandenburgian's first pirating-trips to the Caribbean, the "Brandenburgisch-Afrikanische Kompagnie" was founded in 1682, heavily manned with Dutchmen and also Huguenots, and renamed in 1692 "Brandenburgisch-AfricanischeAmericanische Compagnie." By mutual agreement, the East Frisian port of Emden was declared the main port of Brandenburg's fleet.

We cannot follow the development of Brandenburg's trading posts and settlements more closely here, but should still note that Brandenburg got involved in the lucrative slave trade and that, in 1686, a first ship reached the island of St. Thomas in the Caribbean, jointly used with Denmark, with 450 slaves out of Großfriedrichsburg. More slave ships were to follow (Lennert, 2004: 16): The hopes for great profits and an increase in power seemed to be fulfilling themselves. Brandenburg's settlement on St. Thomas soon counted 300 Europeans and some hundreds of slaves. Scientists assume today that about thirty thousand slaves were deported from Africa to the West Indies by slavers from Brandenburg (Lennert, 2004: 17). Despite the attempts of Elector Frederick III., who had assumed the succession of the Great Elector in 1688 and, since 1701, bore the title of a king in Prussia, to continue the colonial ambitions and activities: The "Brandenburgisch-Africanische-Americanische Compagnie" was riddled with debt and was finally liquidated by Frederick Wilhelm I., who had been in office since 1713, at a moment in time when the colonial business in the ensemble of European powers had stopped appearing lucrative, especially since the second phase of accelerated globalization still was nowhere in sight. In 1738 -only three decades before the publication of the work on America by the philosophe who was under Frederick II.'s special protection- the last belongings of the "Compagnie" were being auctioned off (Lennert, 2004: 23). Prussia's failed colonial politics 
would only be resumed after the foundation of the German Reich in 1871.

Certainly, it simply seems impossible from today's scientific standpoint to exclude the possibility that de Pauw might have been thinking about resuscitating Brandenburg-Prussian colonial politics and, herewith, revivifying the Dutch tradition of such enterprises. But it seems much more important to me in this context that through the Recherches philosophiques sur les Américains and the ensuing debates with Antoine-Joseph Pernety, Zaccaria de Pazzi de Bonneville, Giovanni Rinaldo Carli, Delisle de Sales, Francisco Javier Clavijero, Drouin de Bercy and many others, Potsdam and Berlin temporarily moved to the center of an international debate about the non-European world which would continue until well into the nineteenth century. From today's point of view, this time-span can certainly be seen as a very relevant period in the history of ideas, a period, one must say, that historiography has largely permitted to slip into oblivion, just like the colonial history of Brandenburg and Prussia in the late seventeenth and early eighteenth centuries. For an archeology of globality in the sense presented here, these public debates and conflicts with their international resonance are therefore highly relevant if one wants to make sure that this historical period isn't completely forgotten, at least in Berlin and Brandenburg.

\section{WORLD TRADE AND WORLD HISTORY AS A WORLD IN TRANSITION}

Up to what point the international debates taking place before the backdrop of British, French, but also Spanish or Russian scientific expeditions during the second phase of accelerated globalization changed the significance of nonEuropean subject matters in general and, more specifically, of questions concerning the New World, can be elucidated by having a look at the French Encyclopédie. The first volume of this great collaborative effort of European Enlightenment, published in 1751 , only dedicated a couple of lines to the entry "Amérique": no more than for the entry "Amer" (bitter) and much less than for "Améthyste." In the entry "Amérique" one learns that America is one of the four parts of the world, that it was discovered in 1491 (sic!) by the Genovese Columbus, and that it got its name from "AméricVespuce Florentin", who reached the New World in 1497 (Encyclopédie, 1751: 356). In what follows, we learn little more than that the continent is divided into South and North America and that the South offers gold and silver, apart from a long list of other colonial goods, and that the North supplies -and this should hardly astonish usbadger furs (Encyclopédie, 1751: 356).
In the supplement to the Encyclopédie that I already mentioned above, published in 1776 in Amsterdam, the entry "Amérique" comprises no less than circa twenty pages in dense print. The length of the entry had increased by a factor of seventy in the course of two decades. The first and significantly longer section (of two) was penned by Cornelius de Pauw, who chose to use a much less polemical and more moderate language here (Pauw, 1776). With the sovereign gesture of a (source-) critical Enlightenment thinker, de Pauw excluded from his reflections, as in his Recherches philosophiques, absolutely all of the old chronicles, documents and reports as completely untrustworthy. According to de Pauw, one is confronted there not only with the "crédulité d'un enfant," but also with the "délires d'un vieillard" (Pauw, 1776: 344). Now the Dutch Abbé had cleared enough room to present once more his theses in full detail in a prominent and prestigious spot to an international public of readers. It is no coincidence that America and the debates about the New World in the context of a new wave of globalization were now taking up much more space in and around the Encyclopédie.

It is significant and, at the same time, comes as no surprise that Raynal's oeuvre, highly complex in its genesis and écriture, that has been viewed with good reason as an encyclopedia of European colonial expansion and was to become one of the big bestsellers of the French eighteenth century (Lüsebrink, 1988), uses in many places the same discursive strategies and traditions in order to win the internationally widely spread public's interest for the subject matter it treats on thousands of pages. So we read, right in the "Introduction" to the first volume of the Histoire philosophique et politique des établissements et du commerce des européens dans les deux Indes, in formulations which remind us of the first lines of Cornelius de Pauw's Recherches philosophiques sur les Américains or of his article in the Encyclopédie's supplement:

\footnotetext{
“Il n’y a point eu d'événement aussi intéressant pour l'espèce humaine en général, \& pour les peuples de l'Europe en particulier, que la découverte du Nouveau Monde \& le passage aux Indes par le cap de BonneEspérance. Alors a commencé une révolution dans le commerce, dans la puissance des nations, dans les moeurs, l'industrie et le gouvernement de tous les peuples. [...]

Tout est changé, \& doit changer encore. Mais les révolutions passées \& celles qui doivent suivre, ontelles été, seront-elles utiles à la nature humaine? L'homme leur devra-t-il un jour plus de tranquillité, de bonheur \& de plaisir? Son état sera-t-il meilleur, ou ne fera-t-il que changer?'” (Raynal, 1781, I: 1 f.)
} 
With these words, Guillaume-Thomas Raynal, who was an attentive reader of de Pauw's, using an only slightly changed phrasing, took up the discourse on the world-historical moment of the socalled discovery of America. At the same time, he extended the "West Indian" perspective programmatically to comprise also the "East Indian," herewith according trade - as the title of his colonial encyclopedia announces - an important, even decisive role in the radical changes that had marked the world so fundamentally ever since the end of the fifteenth century. But this view on the first phase of accelerated globalization was supplemented by the insight that the révolutions unleashed by it would be followed in the present and the future by new upheavals, which were to bring more fundamental changes. It remained to be seen, what consequences they were going to have on human fortune and wealth.

Herewith, the Histoire des deux Indes' incipit stages an archeology of globality from the conscience of a duplicated globalization, which is continuously elaborated as the many volumes of the work progress: the globalization of the late fifteenth and sixteenth centuries and that of the second half of the eighteenth century. The future of these radical changes - as much as their own history - seemed to be completely open. But the propulsive force and dynamic of such a world in transition is world trade. So the figure of the philosopher, whose voice repeatedly generates cohesion between the heterogeneous, often contradictory parts of the Histoire des deux Indes, begins by taking a look at a Europe predating the epoch of the discoveries - "l'Europe avant les découvertes" (Raynal, 1781, I: 2) -, then gains a higher point of observation which encompasses the whole world and underscores from an almost extraterrestrial perspective the fundamental relevance globalized trade has for the entire planet:

\footnotetext{
"Elevé au-dessus de toutes les considérations humaines, c'est alors qu'on plane au-dessus de l'atmosphère, \& qu'on voit le globe au-dessous de soi. C'est de-là qu'on laisse tomber des larmes sur le génie persécuté, sur le talent oublié, sur la vertu malheureuse. [...] C'est de-là qu'on voit la tête orgueilleuse du tyran s'abaisser \& se couvrir de fange, tandis que le front modeste du juste touche la voûte des cieux. C'est là que j'ai pu véritablement m'écrier, je suis libre, \& me sentir au niveau de mon sujet. C'est là enfin que, voyant à mes pieds, ces belles contrées où fleurissent les sciences \& les arts, \& que les ténèbres de la barbarie avoient si long-temps occupées, je me suis demandé: qui est-ce qui a creusé ces canaux? qui est-ce qui a desséché ces plaines? qui est-ce qui a fondé ces villes? qui est-ce qui a rassemblé, vêtu, civilisé ces peuples? \& qu'alors toutes les voix des hommes
}

éclairés qui sont parmi elles m'ont répondu: c'est le commerce, c'est le commerce." (Raynal, 1781, I: 3 f.)

Not only was the rhetoric of the Histoire des deux Indes, which plays with a sophisticated economy of reader-figures (Ette, 1998), more effective in creating a greater resonance in the public of readers than de Pauw's Recherches philosophiques (Bancarel, 1988 and 1991), but it was also capable of covering more spatial, thematic and philosophical ground, a fact which - due to the incorporation of a wide range of statistical data provided by Raynal, Diderot and the numerous collaborators and correspondents - raised, for many decades, this collective project to the status of a reference for information on the non-European world. Raynal, who, during his exile from France, had only spent a short period of time at the court of Frederick the Great and had been received much less warmly in Germany (compared to France), had started to make the Abbés work look second-rate at the Prussian court ever since the first publication of his Histoire in 1770.

But one has to say that not only in relation to the work of Cornelius de Pauw, relying on crass antinomies, but also concerning Guillaume-Thomas Raynal's Histoire des deux Indes the great time of heated debates and scholarly discussions was slowly cooling down and, finally, coming to an end when the transition into the nineteenth century occurred. It is, of course, of merely anecdotic importance that this was triggered by a man who, in 1769, had been born in Berlin, the place where the second volume of the Recherches philosophiques sur les Américains had just been published; but one cannot fully deny this fact its symbolic value.

It is highly significant that one of the Dutchman's most outstanding critics, Drouin de Bercy, who claimed to have spent time in Saint-Domingue as a French Colon, to have participated as an officer in the French army's unlucky expedition under general Leclerc against the Haitian Revolution and to have spent a total of thirteen years in America, attacked Cornelius de Pauw forty years after the first edition of the Recherches philosophiques sur les Américains by confronting de Pauw with Alexander von Humboldt in his two-volume book L'Europe et l'Amérique comparées, published in Paris in 1818: "His chief method of refuting De Pauw is to confront him with statements from Alexander von Humboldt, whom he quotes as absolute authority" (Church, 1936: 204). The younger of the two Humboldt brothers, who had for many years settled down in Paris after returning from his long travels with Aimé Bonpland in America (from 1799 to 1804), had long since been the ultimate authority in the discourse on the American hemisphere. A new discourse about the New World had arisen, and once more Potsdam 
and Berlin were to play an important role in this discourse during the second half of the nineteenth century.

\section{A REFLECTION ON GLOBALITY BEYOND RADICAL OTHERNESS}

For the discourse about the non-European regions and especially America had begun to undergo a fundamental transformation at the beginning of the nineteenth century. Alexander von Humboldt, who had published after his return from the Reise in die Aquinoktial-Gegenden des Neuen Kontinents ("Personal Narrative of a Journey to the Equinoctial Regions of the New Continent") between 1805 and 1838 a huge work on travel in thirty splendid large-format folios and numerous smaller editions and translations, knew very well what he was talking about when he wrote in his introduction to Vues des Cordillères et Monumens des Peuples Indigènes de l'Amérique, dated Paris, April 1813:

\begin{abstract}
“L'ardeur avec laquelle on s'étoit livré à des recherches sur l'Amérique, diminua dès le commencement du dix-septième siècle; les colonies espagnoles, qui enferment les seules régions jadis habitées par des peuples civilisés, restèrent fermées aux nations étrangères; et récemment, lorsque l'abbé Clavigero publia en Italie son Histoire ancienne du Mexique, on regarda comme très-douteux des faits attestés par une foule de témoins oculaires souvent ennemis les uns des autres. Des écrivains célèbres, plus frappés des contrastes que de l'harmonie de la nature, s'étoient plu à dépeindre l'Amérique entière comme un pays marécageux, contraire à la multiplication des animaux, et nouvellement habité par des hordes aussi peu civilisées que les habitans de la mer du Sud. Dans les recherches historiques sur les Américains, un scepticisme absolu avoit été substitué à une saine critique. On confondoit les descriptions déclamatoires de Solis et de quelques autres écrivains qui n'avoient pas quitté l'Europe, avec les relations simples et vraies des premiers voyageurs; il paroissoit du devoir d'un philosophe de nier tout ce qui avoit été observé par des missionnaires.
\end{abstract}

Depuis la fin du dernier siècle, une révolution heureuse s'est opérée dans la manière d'envisager la civilisation des peuples et les causes qui en arrêtent ou favorisent les progrès. Nous avons appris à connoître des nations dont les moeurs, les institutions et les arts diffèrent presque autant de ceux des Grecs et des Romains, que les formes primitives d'animaux détruits diffèrent de celles des espèces qui sont l'object de l'histoire naturelle descriptive. La société de Calcutta a répandu une vive lumière sur l'histoire des peuples de l'Asie. Les monumens de l'Egypte, décrits de nos jours avec une admirable exactitude, ont été comparés aux monumens des pays les plus éloignés, et mes recherches sur les peuples indigènes de l'Amérique paroissent à une époque où l'on ne regarde pas comme indigne d'attention tout ce qui s'éloigne du style dont les Grecs nous ont laissé d'inimitables modèles." (Humboldt, 1989: 96 and II f.)

In this equally unequivocal and programmatic, scholarly and neutral passage, Alexander von Humboldt -who could certainly be described as an always competent and elegant French writerpresents the transition into the nineteenth century as the brink of a new epoch, an epoch characterized by a "fortunate revolution" in the discourse on the non-European world. Evidently, this passage -like many others in Humboldt's work - is in fact a direct response to the theses and ideas of Raynal's and mostly of de Pauw's, whose Recherches philosophiques sur les Américains are opposed by Humboldt's reflections on the cultures of the "indigenous people in America." Step by step, the theses of the Dutch Abbé are refuted here by proving the existence of great cultural developments in the American peoples on the basis of his own analyses in America, but also in the American and European libraries and archives. Needless to say, de Pauw's name hardly ever appears in Humboldt's writing.

It is noteworthy, though, that he only explicitly named one author in the above-quoted passage, this author -Francisco Javier Clavijero- being intimately connected to the pre-Colombian history of the Spanish colonies in America as a representative of the Enlightenment in Spanish America, but also well-informed about the present state of what later was to be Mexico. Also, Clavijero -literally as an American representative in Europe- had led the most massive and best-founded attacks against de Pauw up to this date. In his Storia Antica del Messico (Clavijero, 1780), first published in Italy and in Italian after the expulsion of the Jesuits from the colonies, he had vehemently attacked all those European scholars who, like Buffon, de Pauw, Raynal, or Robertson, had written about America and the Americans without ever having set foot in the New World. Discretely but unequivocally, Humboldt herewith marked his own position within the dispute over the New World and at the same time let American authors have their say.

Already Pernety had made clear that, as opposed to the Dutchman he was criticizing, he had actually been in the New World himself. So Humboldt could even more legitimately refer to himself as an "eyewitness" and distance himself from Buffon, de Pauw or Raynal in an epistemological sense. He knew: A new, empirically founded, historically oriented and comparative discourse about what was "outside" Europe was about to arise. The dominance of a perspective 
which had lasted for decades, brought forward by famous writers, representing America as a swampy continent that had only recently emerged from the water and was inhabited by feeble and weak beings -and this was definitely and mainly referring to Buffon and de Pauw, but also to Raynal- had been broken. The saine critique had won over the scepticisme absolu of the Enlightenment's philosophes, who had rejected the old reports as lies because they did not fit their own systematical thinking-structures. Particularly in his Vues des Cordillères et Monuments des Peuples Indigènes, his "views on the indigenous cultures," Humboldt had started to change the perspective on the New World also in cultural matters, not conceptualizing it as the radical Other anymore, as it had been the case ever since the first reports of European mariners.

What was more: This new way of looking at things was integrated into a wave of scientific investigations encompassing the whole world, analyzing Asia and Europe, Egypt and ancient Greece, India and the Roman Empire from a comparative perspective and inserting them into a worldwide net of empirically founded reflections. It was up against this backdrop that, starting in 1805, Humboldt unfolded an incredibly wide array of the most diverse scientific inquiries, which, in the spirit of a globalized and simultaneously globalizing science, constantly discussed their own findings from a globally comparative and transdisciplinary perspective. Hereby he does not take science-despite some restrictions- to be a destructive force serving European expansionism, but to be a practice of knowledge committed to all of mankind. The fact that Humboldt, in contrast to his explanations mentioned above, did not always refrain from considering Greek antiquity as the cultural-historical and artistic meridian on his map of the cultures of the world has to be seen as one of the contradictions which are imminent to his -nevertheless ground-breaking - project of a different modernity (Ette, 2002).

Seen from this perspective of a globalizing concept of science which also captures its own historicity, it can only be a logical consequence that, in the context of his work on his American travels, Humboldt not only addressed the geography of plants and the views on nature, zoological observations and the American indigenous cultures, trigonometric measurements, political and national-economic analyses, but that he also (and especially) took into consideration the historical period which I have earlier denominated the first phase of accelerated globalization. What had initially been devised as an explanatory addition to the cartographic work Atlas géographique et physique des régions équinoxiales du Nouveau Continent had developed bit by bit, edition by edition, an intellectual life of its own, which turned it into one of the most fascinating pieces of his work. Humboldt finally gave it the lengthy title Examen critique de l'histoire de la géographie du Nouveau Continent et des progrès de l'astronomie nautique aux quinzième et seizième siècles. It is true that this "textual part" of the atlas-work, published in French between April 1834 and August 1838, was to remain a fragment, like many of Humboldt's great works (Fiedler and Leitner, 2000: 152-165). At the same time, from the first sentence of the "Préface" on, dated Berlin, November 1833, it unfolded considerable accuracy and charm not only in the historiographic sense, but also concerning the philosophy of history. Reading it is quite an experience even today:

\begin{abstract}
"Les siècles dans lesquels se révèle la vivacité du mouvement intellectuel, offrent le caractère distinctif d'une tendance invariable vers un but déterminé. C'est l'active énergie de cette tendance qui leur imprime de la grandeur et de l'éclat. Une suite non interrompue de découvertes géographiques, effet d'une noble communauté d'inspiration et d'ardeur chez les Portugais et les Castillans, une lutte sanglante prolongée par la réaction de la réforme religieuse, des mouvemens politiques tendant à refondre les institutions sociales, ont occupé successivement les esprits et donné à certaines périodes une physionomie individuelle.
\end{abstract}

Le quinzième siècle, dont je m'occupe de préférence dans cet ouvrage, offre un intérêt qu'on pourrait appeler de position dans l'échelle chronométrique des progrès de la raison. Placé entre deux genres de civilisation, il offre comme un monde intermédiaire appartenant à la fois au moyen-âge et aux temps modernes." (Humboldt, 1836, I: VII f.)

It is typical for Humboldt's thinking that he as the scientist investigating nature and culture, as in the preface to his Kosmos, dated Potsdam, November 1844 -there the incipit reads: "Ich übergebe am späten Abend eines vielbewegten Lebens [...]" ("In the dusk of a restless life, I deliver [...]") (Humboldt, 2004: 3)-, combined the lexemes of movement and life (e. g. of what is alive), which were so important and decisive for him. In the end, all of the Examen critique, maybe even all of Alexander von Humboldt's work was concerned with the most diverse forms of expression and combination that life and movement take on, with this vivacité $d u$ mouvement intellectuel, defining in this historical and historical-philosophical sketch a century's physiognomy, a century which is designated as a "world in-between," as a monde intermédiaire between the Middle Ages and modernity. So not just the movements in space, the uninterrupted sequence of voyages and discoveries, but also (and 
especially) the intellectual motions constitute for Humboldt the center of geographic and historiographic inquiries, as well as being the nucleus of questions concerning the philosophy of history and the history of ideas, all being related to the dynamics of how knowledge arises and disseminates in space.

\section{AN ARCHEOLOGY OF GLOBALITY AS A HISTORY OF MOVEMENTS}

For a good reason, Andreas Daum has reminded us of the fact that the Humboldtian approach can be understood as a history of space and that it created a worldwide range of applications (Daum, 2000). But since in the Examen critique Humboldt was not just interested in generating knowledge locally or regionally, but in reimplanting or transferring it, one could -apart from a spatial turn (Schlögel, 2003) that has been repeatedly proclaimed- speak of a history of movements in the strictest sense of the word.

Seen from this angle, Humboldt's interest is a profoundly vectorial one. For on the one hand it searches for the transregional, transareal and transcontinental relations between space and knowledge, but, on the other hand, it also tries to unearth once more the vectorially inscribed movements in the contemporary movements of knowledge and attempts to represent them as clearly as possible in a history of knowledge. This specifically vectorial dimension of his approach aims at uncovering, anagrammatically, so to say, the movements underneath the movements in an archeology that can be considered an archeology of globalization in the fullest sense of the word. But the latter may only be conceptualized -this the Examen critique's history of movement seems to imply- as an archeology of mobility.

Humboldt's Examen critique of the fifteenth and sixteenth centuries, fascinating to this day, follows a multi-faceted and ingenious pattern. So one can show that, also in the Examen critique, Alexander von Humboldt's image (who -as the Prussian certainly knew- would have carried the name Humboldt y Colomb in Spanish-speaking countries, after the Huguenot family on the maternal side) is connected anagrammatically to the figure of Christopher Columbus or Cristóbal Colón, given the fact that both "discoverers" traces superimpose themselves, sometimes in an obsessive fashion (Ette, 1992). If we just look at the Examen critique, the image of Humboldt becomes visible en filigrane, so to speak, "behind" that of Columbus. But if we look in the other direction and ask for the Examen critique's functionality within all of the work on the travels, of which it forms the keystone in a certain sense, then we see a different, even more exciting picture. For as in an archeology of movement, the movements of the European discoverer par excellence become visible "under" the spatial and intellectual movements of the Prussian traveler and historiographer, who - as he also knew - would soon be celebrated as the "second discoverer" of Cuba and of that space which we today denominate Latin-America. Already Cornelius de Pauw had made the following remarks on Columbus, who he - like most of the eighteenth century's philosophes considered a "grand homme" and admired, picking up on an old and repeatedly voiced suspicion:

"Christophe Colomb au contraire découvrit en 1492 une route aisée; \& quand on le voit s'élever jusqu'au XXV degré de latitude nord, pour saisir ce vent d'est qui regne ordinairement entre les tropiques, \& aller ensuite presque en droite ligne à l'île de SaintDomingue, on seroit tenté de croire qu'il savoit cette route d'avance [...]." (Pauw, 1776: 344)

This is certainly not the place to suspect, on our part, other movements under the movements Columbus made and to follow up on the thesis that an earlier discoverer might have passed on his knowledge to the Genovese. In the Examen critique, Humboldt could rely on science's most recent findings concerning spatial and intellectual movements in the fifteenth century, as well as on the transcripts, found only a few years earlier, that Bartolomé de las Casas had made of Colón's logbook. In his philosophically and philologically founded analysis, Humboldt managed like nobody else before him to disentangle and read a stratified and intertwined texture of the documents and fictions, sources and prophecies, travel logs and spiritual truths which make the "discoverer's" deeds intelligible. The Examen critique shows very clearly which ways of knowledge Cristóbal Colón translated into those routes in space to which he entrusted his ships and crews on the supposed trip to India, without anybody else, who by chance might have been washed up on those western shores, having to provide him with information about this opportunity. Right at the beginning of his examinations, Humboldt made clear that the great discoveries that characterized Europe's movement of expansion had not just been brought about by chance:

\footnotetext{
“Les grandes découvertes de l'hémisphère occidental ne furent point le résultat d'un heureux hasard. Il serait injuste d'en chercher le premier germe dans ces dispositions instinctives de l'ame auxquelles la postérité attribue souvent ce qui est le résultat d'une longue méditation. Colomb, Cabrillo, Gali, et tant d'autres navigateurs qui, jusqu'à Sébastien Viscayno, ont illustré les annales de la marine espagnole, étaient,
} 
pour l'époque à laquelle ils vivaient, des hommes remarquables par leur instruction." (Humboldt, 1836, I: 7 f.)

The history of the discoveries, for Humboldt, is therefore literally identical with a history of knowledge and its translation into movement. For "America's historiographer,", 14 a designation he liked to pride himself with, the thread he had woven into his text with considerable satisfaction, tying him to the Genovese, merely represented an element of a much wider movement which gives his Examen critique, but also his other works, their specific location in history. Herewith the historiographic work itself becomes a part and a characteristic of a form of globality which may only conceptualize itself as such when it is aware of its own history. So globality is closely interconnected with its own archeology.

Already in the preliminary words of his work on the history of the discoveries, Humboldt underscored the importance the work had for him, "auquel, pendant trente ans, je me suis livré dans tous mes momens de loisir et avec une extrême predilection" (Humboldt, 1836, I: X); still, Humboldt stated that by no means did he regret having invested so much time and effort into his inquiries, for it is "le devoir de l'historien" to discern in every century "le caractère individuel et les traits distinctifs de son mouvement intellectuel" (Humboldt, 1836, I: 191) - a phrase with which this key notion of Humboldtian thinking is named once more. Humboldt all too willingly fulfilled this obligation of the historian, which consists in making these distinctive traits visible, from a consciously reflected historical distance and, at the same time, difference:

\footnotetext{
"Au milieu des idées qui gouvernent le dix-neuvième siècle, pendant l'essor prodigieux d'une civilisation qui avance et ne vit, pour ainsi dire, que dans le présent et pour un avenir très prochain, on a de la peine à comprendre une époque glorieuse pour le genre humain où, aprés avoir fait de grandes choses, on se plaisait à jeter les yeux en arrière, à scruter patiemment si ces grandes choses étaient l'accomplissement d'antiques prédictions." (Humboldt, 1836, I: $190 \mathrm{f}$.)
}

The framework of these "Critical examinations" consists of the difference between a cyclical consciousness of history, where historia is and remains the magistra vitae (Koselleck, 1984), and an openended understanding of history, typical of modernity, which was part of - as Goethe wittily formulated it - a "velociferian age"15 with its devilishly velociferian acceleration. The Examen critique attempts to understand the present not just by looking at the distance it has gained from phenomena of historical emergence, but by understanding the present itself as linked to the process of historical emergence and development. This applies especially to a multi-volume work about travels which also attempts to answer the questions arising from the second phase of accelerated globalization by examining critically the first phase of accelerated globalization and by grounding its analysis in philology and the philosophy of history. The central aim here is to try to analyze the interactions and reciprocal interconnections between the Old and New World in space and time and to elucidate in this way those transfers of knowledge which dealt with the creation and development of new knowledge, especially with its distribution in a spatial sense. In this sense, Columbus turns into a kind of mediator for knowledge and, even more so, a mover of knowledge belonging to an interstitial world, who made his appearance on the stage of the "théâtre du monde" in order to multiply the objects on the horizon of European thought and to abruptly increase "la masse des idées" (Humboldt, 1836, III: 153). But this notion, which basically follows Voltaire, is elevated by Humboldt, in a double movement in which he is less interested in the arising as, rather, in the interlinking of knowledge, to the level of a globalized concept of history in view of the distribution of knowledge and the transfer of ideas:

\begin{abstract}
"En rappelant ce que la pensée de deux hommes, Toscanelli et Colomb, a ajouté à l'esprit humain, il ne faut pas se borner aux étonnans progrès qu'ont faits simultanément la géographie, le commerce des peuples, l'art de naviguer et l'astronomie nautique, toutes les sciences physiques en général, enfin la philosophie des langues, agrandie par l'étude comparée de tant d'idiomes bizarres et riches de formes grammaticales. Il faut envisager surtout l'influence qu'a exercée le Nouveau-Continent sur les destinées du genre humain sous le rapport des institutions sociales. La tourmente religieuse du seizième siècle, en favorisant l'essor d'une libre réflexion, a préludé à la tourmente politique des temps dans lesquels nous vivons. Le premier de ces mouvemens a coïncidé avec l'époque de l'établissement des colonies européennes en Amérique; le second s'est fait sentir vers la fin du dix-huitième siècle, et a fini par briser les liens de dépendance qui unissaient les deux mondes." (Humboldt, 1836, III: 155)
\end{abstract}

Herewith Humboldt expands the "influence" of European-American relations to encompass just those political and social developments and upheavals which so far had almost exclusively been understood from the standpoint of a purely European context (Humboldt, 1836, III: 155). He is involved here in an archeology of globality in which phenomena and developments of the present gain a 
peculiar transparency when and if the preceding developments and movements of earlier times in a global dimension become visible. So, consequently, Alexander von Humboldt was not just thinking of those long-term effects that the inquiry into American languages and the establishment of first grammar-books in the sixteenth century had on contemporary reflections in the philosophy of language at the beginning of the nineteenth century, a development in the history of science in which he was much involved, not only as a collector and purveyor of material to his brother Wilhelm, but also as a ground-breaking thinker of new linguistic concepts (Trabant, 2005). At the same time, he strove to understand the European institutional and social history from the vantage point of its global contexts, that is, all that had changed "puisamment [...] la face politique et les destinées de l'Ancien-Continent" (Humboldt, 1836, III: 158)' In this passage, he also undertook this project in view of the movements of independence in the European colonies on the American continent, which had largely come to a conclusion at this historical point in time and which, in their foundations and their progress toward Independencia in Spanish-America, he had seemingly accompanied step by step and critically reflected in his own work on America. In this oscillating movement between two timeframes, which traverses all of the Examen critique (See also Humboldt, 1836, III: 296), the history of Europe in a global context gains multidimensionality through the uncovering of its worldwide relationality, a quality one hardly ever finds in today's historiography. Europe's history, this Humboldt knew, couldn't be adequately understood from a purely European standpoint: Without the history of the New World, the history of the Old World had to appear strangely reduced, even amputated in a certain sense.

But, at the same time, Humboldt drew attention to - as we would put it today - structural continuities between certain phenomena of globalization, continuities which connected the first and the second phase in a tragic manner:

\footnotetext{
"Telle est la complication des destinées humaines que ces mêmes cruautés qui ont ensanglanté la conquête des deux Amériques, se sont renouvelées sous nos yeux, dans des temps que nous croyons caractérisés par un progrès prodigieux des lumières, par un adoucissement général dans les moeurs, et cependant un même homme, à peine au milieu de sa carrière, a pu voir la terreur en France, l'expédition inhumaine de Saint-Domingue, les réactions politiques et les guerres civiles continentales de l'Amérique et de l'Europe, les massacres de Chio et d'Ipsara, les actes de violence qu'ont fait naître tout récemment, dans la partie méridionale des Etats-Unis, une atroce législation concernant les esclaves, et la haine de ceux
}

qui voudraient la réformer." (Humboldt, 1836, III: 317 f.)

Of course, the fact that violence, repression and human temper had remained unchanged as "les mêmes au dix-neuvième comme au seizième siècle" (Humboldt, 1836, III: 318) and that they unmasked themselves, equally, in France's expedition of chastisement against the Haitian Revolution ${ }^{16}$ and in the legislation on slavery in the southern states of the USA, despite the Enlightenment and all of philosophy, didn't mean for Humboldt that he had to give up all hope. Rather, he saw a "tendance moderne" in the "perfectionnement des institutions" and also in the perfecting of the "ordre social" (Humboldt, 1836, III: 319), so that despite all -certainly justified - scepticism he didn't feel the need to abandon his project of a different modernity (Cfr. Ette, 2002). For the Humboldtian project of modernization relied explicitly on attempting to draw the conclusions from the acts of violence in the transatlantic processes of globalization and on elucidating a national or European history always from the perspective of a world-historical relationality. In Humboldtian science, thinking in terms of relational wholeness and uniting the multitude of individual phenomena did not only apply to natural phenomena, but also to culture - and specifically the history of humankind. It was the latter that had to be conceptualized in its historical process of emergence and, therefore, as a string of different, but still basically continuous phases of globalization. This favored the thoughtful uniting of particular or national history (or histories) to form a notion of history presenting many intersections and enlacements. The Examen critique represents the first, important step on the road to a concept of history which brings together space and time in their combination as a history of movement and, most relevantly, which is interested in the transfer and translation of knowledge: thinking globality as an archeology of its mobility.

One could multiply the instances of a soconceived archeology, an archeology which looks for the phenomena of globalization dating from earlier centuries under today's phenomena of globalization. They refer to an understanding of history that always also reflects on its global dimensions in order to represent historical change as a history of movements and exchange. Awareness of globality inevitably demands a carefully nuanced historical understanding of mobility.

Concerning America, Humboldt, like de Pauw, emphasized the incredible speed with which an asymmetrical constellation of power had established itself between the Old and the New World, given the fact that in only six years -between 1492 and 1498- the "Verteilung der Gewalt über die Erdoberfläche" ("distribution of power over the 
earth's surface") had been decided and an "Übermacht der Völker des Westens" ("overpowering might of the Western peoples") had been secured (Humboldt, 1836, IV: 21). We shouldn't let us be blinded by the striving for a future equiponderance, visible in all of Humboldt's oeuvre: for this scholar and investigator, power and violence are from the very beginning the decisive elements that form the structure of the European-American relations. But, still according to him, this uneven balancing of power also brought with it a new arrangement of knowledge, so creating new ways of knowledge which, at the threshold of the sixteenth century, were establishing themselves on a global scale. So, at the end of the fourth volume of his Examen critique, Humboldt exclaimed, what a century this must have been, a century in which so many new paths were traced and thoughts newly conceived, in which the progress of intelligence and of human civilization had so "mächtig beschleunigt" ("mightily accelerated"). ${ }^{17}$

But herewith this period in time is also inserted into the history of world consciousness which, according to the author of the Kosmos, began in the eastern Mediterranean:

\footnotetext{
"Was aber, wie schon oft bemerkt worden, die geographische Lage des Mittelmeers vor allem wohlthätig in ihrem Einfluß auf den Völkerverkehr und die fortschreitende Erweiterung des Weltbewußtseins gemacht hat, ist die Nähe des in der kleinasiatischen Halbinsel vortretenden östlichen Continents; die Fülle der Inseln des ägäischen Meeres, welche eine Brücke für die übergehende Cultur gewesen sind; die Furche zwischen Arabien, Aegypten und Abyssinien, durch die der große indische Ocean unter der Benennung des arabischen Meerbusens oder des rothen Meeres eindringt, getrennt durch eine schmale Erdenge von dem Nil-Delta und der südöstlichen Küste des inneren Meeres. Durch alle diese räumlichen Verhältnisse offenbarte sich in der anwachsenden Macht der Phönicier und später in der der Hellenen, in der schnellen Erweiterung des Ideenkreises der Völker der Einfluß des Meeres, als des verbindenden Elementes. Die Cultur war in ihren früheren Sitzen in Aegypten, am Euphrat und Tigris, in der indischen Pentapotamia und in China an reiche Stromlandschaften gefesselt gewesen; nicht so in Phönicien und Hellas. In dem bewegten Leben des Griechenthums, vorzüglich im ionischen Stamme, fand der frühe Drang nach seemännischen Unternehmungen eine reiche Befriedigung in den merkwürdigen Formen des mittelländischen Meerbeckens, in seiner relativen Stellung zu dem Ocean im Süden und Westen." (Humboldt, 2004: 154)
}

Here the distribution of landmass and water in the Mediterranean region becomes the starting point for a world-historical movement in which one could easily inscribe Alexander von Humboldt's own work as a world traveller, as a historian and philosopher of the world. The fact that the semantic combination of life and movement reappears once more in the "bewegten Leben des Griechentums" ("moved life of the Greeks"), a semantic combination which is of fundamental importance for Humboldt's life science, which is simultaneously also a science about movement, points us towards his archeology of a form of globality whose consciousness can only unfold into a world consciousness when it becomes aware of the movements preceding it. A history of space and a generation and deployment of knowledge, made possible by specific spatial configurations, is so transformed into a history of movement, in the center of which are the vectorial dynamics which store and transform earlier patterns of movement.

This is where, at the very latest, an archeology of globality in Alexander von Humboldt's sense reveals itself to imply an archeology of mobility and relationality, if it aims at developing an understanding which is adequate to the questions of globalization, instead of remaining trapped in an unhistorical symptomatology of surface-phenomena, which nevertheless we encounter quite frequently these days. Therefore Humboldt's interest in Christopher Columbus and Amerigo Vespucci exceeded by far the intentions of a merely historiographical work and attempted, by making the movements under the movements and the globalizations under the globalizations readable, to unfold a life-knowledge which, in the context of the second phase of accelerated globalization, also contained a survival-knowledge: the question how a peaceful coexistence of humans and their different cultures could be guaranteed on a global scale was posing itself with renewed vigor.

Such knowledge about how to live together, this Alexander von Humboldt knew very well, as in every transfer of knowledge, had to rely on the fact "qu'à toutes les époques de la vie des peuples, ce qui tient aux progrés de la raison, a ses racines dans les siècles antérieurs" (Humboldt, 1836, I: XVII). So it's all about making the connection between the different epochs in the life of the peoples.

The conviction, voiced in his foreword to the Examen critique, that the interruption of luminous epochs by dark ages is neither an inevitable fate, nor the principle of individuals' or peoples' lives, was of decisive importance not only for Humboldt's own world-consciousness, but also for his self-consciousness as an intellectual avant la lettre (Humboldt, 1836, I: XVII f.). A concept of globality which recognizes the real precondition of its very existence in its own archeology, in the unearthing of the patterns of movement and reflections preceding it, seems to be the only form of globality which offers the opportunity of not 
having to relive the dark sides, suppressed consciously or unconsciously, in a resurgence of what has been repressed. Such an idea of an archeology of globality could then mark the point at which a world-consciousness transforms into knowledge about how to live together, taken in the sense of knowledge about how to live together in difference.

\section{ACKNOWLEDGEMENTS}

I wish to thank the funds provided by the "Ministerio de Ciencia e Innovación" (Spain), project HAR2010-21333-C03-02 led by Prof. M.A. Puig-Samper. Translation of this text from German by Mark Minnes is fully appreciated. Other versions of this article are also available:

Ette, O. (2010) "Réflexions européennes sur deux phases de mondialisation accélérée chez Cornelius de Pauw, Georg Forster, Guillaume-Thomas Raynal et Alexandre de Humboldt." HiN, XI, 21: 24-39. http://www.uni-potsdam.de/u/romani stik/humboldt/hin/hin21/ette.htm. [accessed 09/February/2012]

Ette, O. (2010) Arqueología de la globalización. La reflexión europea de dos fases de globalización acelerada en Cornelius de Pauw, Georg Forster, Guillaume Thomas Raynal y Alexander von Humboldt. In: Ciencia-Mundo. Orden republicano, arte y nación en América. R. Sagredo Baeza (Ed.), pp. 21-66. Editorial Universitaria-Centro de Investigaciones Diego Barros Arana. Santiago de Chile.

\section{NOTES}

1. Concerning these four phases, see Ette (2004: 169-172).

2. A German edition quickly followed, see Pauw (1769).

3. On Cornelius de Pauw, see Church (1936: $180 \mathrm{ff}$.) and Beyerhaus (1926).

4. In his extensive contribution to the Supplément of the Encyclopédie, written a couple of years later, Cornelius de Pauw will evaluate the world-historical relevance of the so-called discovery of the New World quite similarly; see in this context the opening phrase of the entry "Amérique": "L'histoire du monde n'offre point d'événement plus singulier aux yeux des Philosophes, que la découverte du nouveau continent qui, avec les mers qui l'environnent, forme tout un hémisphère de notre planète [...]" (Pauw, 1776: 343)

5. See in this context Gerhard Steiner's Epilogue "Georg Forsters «Reise um die Welt»" (Forster, 1983: 1015).

6. Forster made use, among others, of a text by Alexander Dalrymple on the fur trade; see Forster (1985: 778).

7. For more information on this, see Ette (2001: 9 and 539).

8. See in this context, among others Church (1936: $189 \mathrm{ff}$.), Duchet (1971: 206), Tietz (1983: 991-993) or Ventura (1991: 341-359)

9. See Gerbi (1983: 99-109), for the best analysis of this phenomenon.

10. See, in this context, for the epistemology of ear and eye Ette (2001: 119-192).

11. For more information, see: Gerbi (1983: 120-125).

12. Nevertheless the existence of this edition, I will keep quoting the first one.

13. Among these elements are "the critique of Eurocentrism; the importance of gathering data in the field and verifying sources; the recognition of the cultural diversity of the Other"'(Mannucci, 1992: 384).

14. Concerning this designation, which Alexander von Humboldt repeatedly claimed as his, see Konetzke (1959).

15. Concerning the Goethean concept and wordplay of the "velociferian," which appears mostly between 1825 and
1827, in connection with Goethe's concept of a world literature, see Bohnenkamp (1999).

16. See in this context an even clearer Humboldt's passage, where we read in connection with an elaboration on gruesome methods of hunting humans in the sixteenth century: "Comme dans les guerres civiles les peuples d'Europe renouvellent toujours les cruautés des temps les plus barbares, l'expédition française de Saint-Domingue, en 1802, nous montre non-seulement des nègres prisonniers brûlés à petit feu, au milieu d'une grande population, mais aussi des chiens de Cuba, qui ont acquis une triste célébrité, employés à la chasse aux hommes." (Humboldt, 1836, III: 374)

17. "Quel siècle que celui où l'histoire contemporaine pouvait offrir de telles images à l'orgueil des races, perpétuer par d'ingénieux emblèmes le souvenir de cet esprit chevaleresque qui, en frayant de nouvelles routes et en agrandissant la sphère des idées, a accéléré puisamment les progrès de l'intelligence et de la civilisation humaine!" (Humboldt, 1836, IV: 335 f.)

\section{REFERENCES}

Albert, Matthias (2002) Zur Politik der Weltgesellschaft. Identität und Recht im Kontext internationaler Vergesellschaftung. Velbrück Wissenschaft, Weilerswist.

Bancarel, Gilles (1988) "Le succès inattendu d'un Rouergat au XVIII ${ }^{\mathrm{e}}$ siècle". Procès Verbaux de la Société des Lettres, Sciences et Arts de l'Aveyron, 45: 218-225.

Bancarel, Gilles (1991) "G. Thomas Raynal: de la séduction à la sévérité". Revue de Rouergue, 28: 477-488.

Beyerhaus, Gisbert (1926) "Abbé de Pauw und Friedrich der Große, eine Abrechnung mit Voltaire". Historische Zeitschrift, 134: 465-493.

Bohnenkamp, Anne (1999) «Den Wechseltausch zu befördern». Goethes Entwurf einer Weltliteratur. In: Johann Wolfgang Goethe, Ästhetische Schriften 1824-1832. Über Kunst und Altertum V - VI, edited by Anne Bohnenkamp, pp. 937964. Deutscher Klassiker Verlag, Frankfurt am Main.

Church, Henry Ward (1936) Corneille de Pauw, and the controversy over his «Recherches philosophiques sur les Américains». PMLA 51: 178-206. http://www.jstor.org/ stable/458321 [accessed 09/February/2012]

Clavijero, Francisco Javier (1780) Storia Antica del Messico. 4 volumes. Gregorio Biasani, Cesena.

Daum, Andreas (2000) "Alexander von Humboldt, Natur als «Kosmos» und die Suche nach Einheit. Zur Geschichte von Wissen und seiner Wirkung als Raumgeschichte". Berichte zur Wissenschaftsgeschichte, 23: 243-268. http://dx.doi.org/ 10.1002 /bewi.20000230303

Deutscher Bundestag (2001) Globalisierung der Weltwirtschaft-Herausforderungen und Antworten. Drucksache 14/ 6910. http://dipbt.bundestag.de/dip21/btd/14/069/1406910. pdf [accessed 09/February/2012]

Duchet, Michèle (1971) Anthropologie et histoire au siècle des Lumières. Buffon, Voltaire, Rousseau, Helvétius, Diderot. Flammarion, Paris.

Encyclopédie, ou Dictionnaire raisonné des Sciences, des Arts et des Métiers (1751) Vol. 1, Entry: Amérique. Chez Briasson, Paris.

Ette, Ottmar (1992) Entdecker über Entdecker: Alexander von Humboldt, Cristóbal Colón und die Wiederentdeckung Amerikas. In: Columbus zwischen zwei Welten. Historische und literarische Wertungen aus fünf Jahrhunderten, edited by Titus Heydenreich, Volume I, pp. 401-439. Vervuert Verlag, Frankfurt am Main.

Ette, Ottmar (1998) Figuren und Funktionen des Lesens in Guillaume-Thomas Raynals «Histoire des deux Indes». In: Ex nobili philologorum officio. Festschrift für Heinrich Bihler zu seinem 80. Geburtstag, edited by Dietrich Briesemeister and Axel Schönberger, pp. 589-610. Domus Editoria Europaea, Berlin.

Ette, Ottmar (2001) Literatur in Bewegung. Raum und Dynamik grenzüberschreitenden Schreibens in Europa und Amerika. Velbrück Wissenschaft, Weilerswist. 
Ette, Ottmar (2002) Weltbewußtsein. Alexander von Humboldt und das Projekt einer anderen Moderne. Velbrück Wissenschaft, Weilerswist.

Ette, Ottmar (2004) Wege des Wissens. Fünf Thesen zum Weltbewusstsein und den Literaturen der Welt. In: Lateinamerika. Orte und Ordnungen des Wissens. Festschrift für Birgit Scharlau, edited by Sabine Hofmann and Monika Wehrheim, pp. 169-184. Gunter Narr Verlag, Tübingen.

Fiedler, Horst and Ulrike Leitner (2000) Alexander von Humboldts Schriften. Bibliographie der selbständig erschienenen Werke. Akademie Verlag, Berlin.

Forster, Georg (1983) Reise um die Welt, edited by Gerhard Steiner. Frankfurt am Main, Insel Verlag.

Forster, Georg (1985) Die Nordwestküste von Amerika, und der dortige Pelzhandel. In: Georg Forsters Werke. Sämtliche Schriften, Tagebücher, Briefe. Vol. V: Kleine Schriften zur Völker- und Länderkunde, edited by Horst Fiedler, KlausGeorg Popp, Annerose Schneider und Christian Suckow. Akademie-Verlag, Berlin.

Foucault, Michel (1966) Les mots et les choses. Gallimard, Paris.

Gerbi, Antonello (1983) La Disputa del Nuovo Mondo. Storia di una Polemica: 1750-1900, edited by Sandro Gerbi. Riccardo Ricciardi Editore, Milano - Napoli.

Humboldt, Alexander von (1836) Examen critique de l'histoire de la géographie du Nouveau Continent et des progrès de l'astronomie nautique aux quinzième et seizième siècles. Vol. 5. Librairie de Gide, Paris.

Humboldt, Alexander von (1989) Vues des Cordillères et Monuments des Peuples Indigènes de l'Amérique. Editions Erasme, Nanterre.

Humboldt, Alexander von (2004) Kosmos. Entwurf einer physischen Weltbeschreibung. Edition and Epiloge by Ottmar Ette und Oliver Lubrich. Eichborn Verlag (Die Andere Bibliothek), Frankfurt am Main.

Konetzke, Richard (1959) "Alexander von Humboldt als Geschichtsschreiber Amerikas". Historische Zeitschrift, 188: 526-565.

Koselleck, Reinhart (1984) Historia Magistra Vitae. Über die Auflösung des Topos im Horizont neuzeitlich bewegter Geschichte. In: Vergangene Zukunft, pp. 38-66. Suhrkamp, Frankfurt am Main

Lennert, Gernot (2004) Kolonisationsversuche Brandenburgs, Preußens und des Deutschen Reiches in der Karibik. In: Preußen und Lateinamerika. Im Spannungsfeld von Kommerz, Macht und Kultur, edited by Sandra Carreras and Günther Maihold, pp 9-30. LIT-Verlag, Münster.

Lüsebrink, Hans-Jürgen (1988) «Die Geschichte beider Indien» - ein verdrängter Bestseller. In: Raynal, Guillaume [sic] and Denis Diderot: Die Geschichte beider Indien. Selecctions and Notes by Hans-Jürgen Lüsebrink, pp. 329-347. Franz Greno Verlag, Nördlingen.

Mannucci, Erica Joy (1992) The savage and the civilised: observations on a dispute between an enlightened writer and an illuminist. In: Studies on Voltaire and the Eighteenth Century, 303: 382-384.
Pauw, Cornelius de (1768-1769) Recherches philosophiques sur les Américains, ou Mémoires intéressants pour servir à l'Histoire de l'Espèce humaine. Vol. 2. Chez Georges Jacques Decker, Imp. du Roi, Berlin.

Pauw, Cornelius de (1769) Philosophische Untersuchungen über die Amerikaner, oder wichtige Beyträge zur Geschichte des menschlichen Geschlechts. Translated by Carl Gottlieb Lessing. Vol. 2. Decker und Winter, Berlin.

Pauw, Cornelius de (1770) Recherches philosophiques sur les Américains ou Mémoires intéressants pour servir à l'Histoire de l'Espèce humaine par Mr. de P. Nouvelle Edition, augmentée d'une Dissertation critique par Dom Pernety; \& de la Défense de l'Auteur des Recherches contre cette Dissertation. 3 Vol. Decker, Berlin.

Pauw, Cornelius de (1776) Amérique. In: Supplément à L'Encyclopédie ou Dictionnaires raisonné des Sciences, des Arts et des Métiers. Par une Société de Gens de Lettres. Mis en ordre et publié par $M^{* * *}$. Vol. 1, pp. 343-362. Chez M.M. Rey, libraire, Amsterdam.

Raynal, Guillaume-Thomas (1781) Histoire philosophique et politique des établissements et du commerce des européens dans les deux Indes. Chez Jean-Léonard Pellet, Imprimeur de la Ville \& de l'Académie, Genève.

Rousseau, Jean-Jacques (1975) Discours sur l'origine et les fondements de l'inégalité parmi les hommes. In: Oeuvres complètes. vol. III. Edition published under the direction of Bernard Gagnebin and Marcel Raymond, and the collaboration for this volume of François Bouchardy, JeanDaniel Candaux, Robert Derathé, Jean Fabre, Jean Starobinski and Sven Stelling-Michaud. Gallimard, Paris.

Schlögel, Karl (2003) Im Raume lesen wir die Zeit. Über Zivilisationsgeschichte und Geopolitik. Carl Hanser Verlag, München-Wien.

Tietz, Manfred (1983) Amerika vor der spanischen Öffentlichkeit des 18. Jahrhunderts. Zwei Repliken auf de Pauw und Raynal: Die «Reflexiones imparciales» von Juan Nuix y Perpiñá und die «México conquistada» von Juan de Escoiquiz. In: Iberoamérica. Historia-sociedad-literatura. Homenaje a Gustav Siebenmann, Vol. 2, edited by José Manuel López de Abiada and Titus Heydenreich, pp. 9891016. W. Fink, München.

Trabant, Jürgen (2005) Ansichten der Sprache. Alexander von Humboldt und die amerikanischen Sprachen. In: Tableau de Berlin. Beiträge zur «Berliner Klassik» (1786-1815) edited by Iwan D'Aprile, Martin Disselkamp and Claudia Sedlarz, pp. 157-182. Wehrhahn, Laatzen.

Ventura, Roberto (1991) Lectures de Raynal en Amérique latine au XVIII ${ }^{\mathrm{e}}$ et au XIX ${ }^{\mathrm{e}}$ siècles. In: Lectures de Raynal. L'«Histoire des deux Indes» en Europe et en Amérique au $X$ VIII $^{e}$ siècle. Actes du colloque de Wolfenbüttel, edited by Hans-Jürgen Lüsebrink and Manfred Tietz, pp. 341-359. The Voltaire Foundation, Oxford.

Zantop, Susanne (1993) Dialectics and Colonialism: the Underside of the Enlightenment. In: Impure Reason: dialectic of Enlightenment in Germany, edited by David W. Wilson and Robert C. Holub, pp. 301-321. Wayne State University Press, Detroit. 